\title{
How Journalists Source Trending Social Media Feeds
}

\section{Gwen Bouvier}

To cite this article: Gwen Bouvier (2019) How Journalists Source Trending Social Media Feeds, Journalism Studies, 20:2, 212-231, DOI: 10.1080/1461670X.2017.1365618

To link to this article: https://doi.org/10.1080/1461670X.2017.1365618

曲 Published online: 12 Sep 2017.

Submit your article to this journal ๘

Џlll Article views: 924

View Crossmark data ¿ 


\title{
HOW JOURNALISTS SOURCE TRENDING SOCIAL MEDIA FEEDS
}

\section{A critical discourse perspective on Twitter}

\author{
Gwen Bouvier 무
}

\begin{abstract}
Media scholars have called for more research to understand the consequences of news outlets becoming increasingly reliant on social media for sourcing stories, and how this is changing the nature of news and the role of the journalist. This also has high relevance for the Critical Discourse Analyst as regards processes of attributing the nature of ideology, where there is a shift away from stories derived from elite sources and official organizations. Using a sample of 26 news stories and a corpus of 40,000 tweets from a feed called \#twowomentravel, which dealt with the journey of two women travelling from Ireland to the United Kingdom for an abortion, this paper uses Multimodal Critical Discourse Analysis to investigate how the discourses from the feed are taken up by the journalists. Findings show an erosion of some of the basic former aspects of journalistic practice related to verification and provision of context as what is "trending" becomes a news definer. Yet those with the skills to understand how it is integrated into news production may use this to disseminate their own ideology.
\end{abstract}

KEYWORDS Critical Discourse Analysis; news; news values; social media; sourcing; Twitter; verification

\section{Introduction}

News production and the role of the professional journalist have changed dramatically over the last two decades (Picard 2014). From the later 1990s there was intense destaffing, syndication and concentration of ownership, where production shifted to multimedia, constant updates and the need to have a greater understanding of producing content for niche advertiser-targeted markets (McChesney 2016). Since the mid-2000s there has also been a shift to the increased integration of news with social media, both as a means of delivery, channelling visitors to home sites, and as a means of generating content (Broersma and Graham 2012; Carlson and Lewis 2015). In journalism studies, in particular, scholars have argued that we still know little about these changes, with some fearing that they have led to an erosion of more valued journalistic skills such as verifying facts, checking sources and providing contextual information (Hermida 2012).

Such questions about the changing nature of news and its integration with social media have particular relevance for Critical Discourse Analysis (CDA), where there has been a tradition of critically assessing how news media communicate dominant ideologies. The process of analysis here involves critical attention to uses of language in order to reveal what kinds of discourses they carry and what kinds of power relations these support, as well as possible inequalities they seek to legitimize and maintain (Fairclough 1992). Here it has been argued that such texts tend to reflect the views of the elite in any society who will seek to maintain their privilege (Van Dijk 1998). Such power interests are also served by 
the structure and nature of news organizations, which are aligned with elite sources and corporate interests (McChesney 2016). But the integration of news with social media raises questions as to how we can characterize the relationship of discursive content to elite interests. What does it mean when "what is trending" becomes a major definer of news content, rather than the views of elites and official organizations?

This paper takes a small step to consider this process through one case study. In 2016, news outlets around the world ran a story based on a trending Twitter feed with the hashtag \#twowomentravel, which had been created by two women to document a journey from Ireland to the United Kingdom where one of them was to have an abortion. Abortions are illegal in Ireland since the 8th Amendment was passed in 1983. Through 29 tweets, which included 19 photographs posted on 20-21 August 2016, @TwoWomenTravel provided reports from different locations: an airport, a taxi, waiting rooms, etc. The tweets provided comments on their feelings at different points, but also made a case that the law should be changed in Ireland, and were presented as part of the "Repeal the 8th" movement. This movement is comprised of many different interest groups who work together to bring about such a change. The tweets were directed personally to Enda Kenny, Ireland's then Prime Minister. \#twowomentravel attracted more than 40,000 tweets over two days (BBC Trending 2016). The story was covered by many news outlets around the world on their websites, particularly in Ireland, the United Kingdom, and the United States. In this paper I am interested in the ways in which the discourses carried by the Twitter feed were taken up by news outlets. I show that in fact \#twowomentravel offers only one particular ideological viewpoint about the situation. Yet, due to the way that journalists work, the discourses it carries are given very special weight.

\section{Social Media as a Source for News}

Since the 1990s and especially since the mid-2000s, the news industry and news production have been transformed. This relates to a range of factors documented and discussed in journalism studies. On one level this can be characterized as economic (Picard $2014,273)$. There has been a decline in interest in news, with falling circulations and diminishing advertising revenue, which has led to closures, restructuring, downsizing, staff reductions and huge changes in working conditions for the journalists who remain (McChesney 2016, 130), where there are simply less time and resources, leading to a kind of existential crisis for journalism professionals (McNair 2013, 77).

On another level, there have been huge changes in the media landscape. The internet, and particularly social media, enables citizens, civil society, and political and business elites to bypass traditional mass media and directly communicate with each other (Paulussen and Harder 2014, 543). The demand of the digital media environment, with requirements for constant updates and massive competition for clicks, has been a challenge to many long-established traditions in journalism and news production, leading also to the need for radically different business models (Picard 2014, 273). Journalists also work in an environment where there are blurring boundaries between citizen journalists, blogger and other communication roles (Carlson and Lewis 2015; Deuze 2007).

Importantly, news has become more integrated into social media which becomes a place where readers access news and where outlets can deliver content tailored to personal needs (Mortimer 2014). Social media itself has also become a core part of sourcing news content (Hermida 2012; Lasorsa, Lewis, and Holton 2012, 20). This could mean breaking 
stories by using citizen journalist reports on Twitter, or having journalists scouring local community networks on social media for locally trending story ideas. At the time of writing, Twitter itself had become what some observers called a part of news production's "technological infrastructure", where news outlets find stories but also where they monitor and copy each other (Paulussen and Harder 2014, 543).

There were celebratory accounts of the use of Twitter to break and source stories, for example in the coverage of earthquakes and uprisings (see Bruno 2011; Newman 2009), arguing that Twitter users take on the role of social sensors of the news (Sakaki, Okazaki, and Matsuo 2010). Such social sensors function as a kind of early warning system that can then be followed up by professional journalists (Bruno 2011). But many scholars were suggesting that there was a great danger that this reliance on social media was creating something of a breakdown as regards some of the bedrock features of journalism and news: that what is delivered is verified fact (James 2009). Also, as Hermida (2012) argued, this could be even more of a problem where journalists have little time and resources, yet are under great pressure to create fresh and updated content. Former traditions of verification and checking require both time and resources. In fact, journalism scholars had already documented the ways that increased reliance on press releases from both official and private organizations had challenged such traditional notions of journalism (Lewis, Williams, and Franklin 2008). But much less was known about social media. This lack of research is highly relevant for Discourse Analysts with their interest in the discourses and ideologies carried by news media, where such media have traditionally been characterized as being channels for elite views (Van Dijk 1998).

\section{Abortion in Ireland}

It is impossible in a research paper to provide a comprehensive account of the situation concerning abortion in Ireland, as regards its history and the different and diverse points of view involved. My aim here is not to do this. Nor here do I wish to evaluate any of the different positions. In this section I want only to show how \#twowomentravel must be understood as one viewpoint in a complex situation.

In Ireland the 8th Amendment was inserted into the Constitution after a referendum on abortion in 1983 (Hogan 2012). The amendment gave equal right to the mother and unborn. This basically meant that a woman could not decide over the life of the unborn foetus in her womb (Bacik 2013, 385). There are frequent polls in Ireland about the amendment, and calls for referendums. These polls are often difficult to interpret and throw up statistics that tend to be used differently depending upon the point of view of whoever is doing the interpreting. To put it in overly simple terms, the polls tend to show that while many may want the law changed and are in favour of a decriminalization of the process, such changes may be of many different degrees. This may not necessarily involve giving complete choice to pregnant women, as is the case in say the United Kingdom where many Irish women travel to in order to get abortions (Collins 2016). In such polls, there tends to be more support for a shift in the law to allow abortions in special kinds of cases, related to foetal deformity, rape and where there is illness in the case of the mother. There have been a number of shocking public cases where women took their own lives in such situations. From one point of view this situation is brutal and oppressive, as has been noted by Amnesty International (2016). 
One strong voice challenging the 8th Amendment has been the Repeal the 8th movement, which is comprised of a diverse range of different groups who seek to overturn the amendment, although such groups individually place emphasis on different levels of change. The Twitter feed \#twowomentravel is one of the voices associated with this movement and it is, as I show, a rather uncompromising voice, where some supporters of Repeal the 8th were themselves highly critical of its nature.

\section{Theory and Methods}

I place this paper within the tradition of CDA (Fairclough 1992; Van Dijk 1998). This is a form of linguistic analysis that is interested in the ways in which language functions in political and ideological processes. The process of analysis involves close critical attention to the choices made in any use of language with a view to revealing what kinds of power relations these support, what kinds of inequalities they seek to legitimize and maintain. Any choice made in language and grammar is neither neutral nor arbitrary, but motivated. Indeed the language choices, concepts and labels that are available to speakers in any society themselves carry traces of power relations and those groups who have power over such definitions (Caldas-Coulthard and Coulthard 1996, xi).

One central concept in CDA is that of "discourse" (Foucault 1972). This term captures the kind of knowledge about the world that is disseminated by different groups to support their own interest. Such discourses may not be immediately obvious to a reader, but can be drawn out through analysis of language and grammar. Such discourses can be thought of as "scripts" which are comprised of participants, events, times, causalities, places, ideas, values, etc. (Van Leeuwen and Wodak 1999). One way to describe motivated use of language by the powerful is to say that they seek to "re-contextualize" social practices for their own interests. This means taking control over the definitions of how events and processes are understood. The aim of the analyst in this case is to draw out what kind of script is represented or signified in a text; and in this script, how are its elements such as participants, processes and settings represented and evaluated?

I also draw here on Multimodal CDA (Machin and Mayr 2012). Here the principles of CDA are applied to different forms of communication. For example, how do photographs, works of art, computer software and clothing communicate discourses (Machin, CaldasCoulthard, and Milani 2016)? How can these be seen to support the ideologies of those in power?

CDA has been used extensively for the analysis of news texts. But authors argue that textual analysis must be placed within an account of production processes or "the social goings on" that lie behind texts (Richardson 2006). In former studies of news this has meant attention to the reliance of news outlets on official sources, on news agencies and on public relations material (Bennett 2016). In a sense, the source of ideology in this case is not so much in the "bias" of the journalist, nor the news outlet, but is built into the news production process. But given the huge changes in news production and the reliance on social media, these social goings on are to some extent changing, as in the case of the reporting of \#twowomentravel.

In the analysis that follows, I am interested in what kinds of discourses or scripts are found in the original Twitter feed and in how these are taken up in news stories. First I analyse the 29 original posts, by \#twowomentravel. Of course these are integrated into the whole of the feed, but I want to draw out some of the key features here that are 
important later when we look at the news stories. Second, drawing on the corpus of 40,000 posts, I tease out the discourses which comprised the Twitter feed as a whole. Third, I analyse the way news outlets reported the story, drawing on a sample of 26 news stories.

\section{Analysis of the Original Tweets by @TwoWomenTravel}

The first stage of this analysis deals with the original 29 tweets posted by @TwoWomenTravel on 20-21 August 2016. These posts present images of scenes from the different locations visited throughout the journey, along with comments. The posts never give any specific information about actual locations, nor do we see any persons in the images. I begin by looking in detail at what the language and images do represent, what is absent, and what kinds of evaluations are present. First the images.

These images include no participants. Settings are generic. We see, for example, an airplane under a bleak grey sky, a concrete wall through a taxi window, the carpet and chairs in waiting rooms (Figures 1-3). It may not be important here to speculate on whether or not this was an actual journey, but rather a set of images used as part of a campaign to symbolize one-though several posts in the \#twowomentravel openly wondered about this. What is important to point out is that these images are highly compelling in the way that they do claim to document; and this, I argue, is one reason the story was taken up by the news outlets.

The settings in these images can be thought about in regards to what Barthes (1964) would suggest as being compellingly "real", precisely because of their ordinariness and bleakness. Such techniques have long been used in documentary films where shots of the unremarkable, often in gritty detail, work as convincing markers of the authenticwhere there is a sense that the camera operator reveals all there is to show (Nichols 1991; Winston 2008). In other words, while such images clearly create drama, it appears that this is natural. There are no attempts to create this through editing or story telling: we see simply "bare reality".

These images also play an important role in the communication of the mental processes of the women. In CDA it has been shown that giving a reader access to the mental processes, in other words the thoughts and feelings of certain participants, is one way to align readers alongside them (Fairclough 1992). This can also be accomplished visually, through things like close-ups, or lingering shots in film (Machin and Mayr 2012). So too these shots are used to communicate the authenticity of the emotions, of the feelings associated with bleakness of generic, unfriendly, settings.

Moving on to the language in these tweets, we find no account of details of experiences, processes or procedures concerning the abortion. The first tweets provide a clear indication that they are documenting the trip, with posts directed also at @EndaKennyTD, Ireland's Prime Minister. They state their solidarity with other women who make the same kind of trip. After this, we find these images always accompanied by mental processes. We find, for example:

boarding, it's chilly.

waiting room no. 2. Feel might collapse from exhaustion. No sleep. Friend calm. Brave.

Pretty ordinary sights, in a place away from home. Can't say it's comforting, though.

Of course, in such a context all these feelings and thoughts would be expected. But in terms of re-contextualization, we can see here that actual events and participants have been 


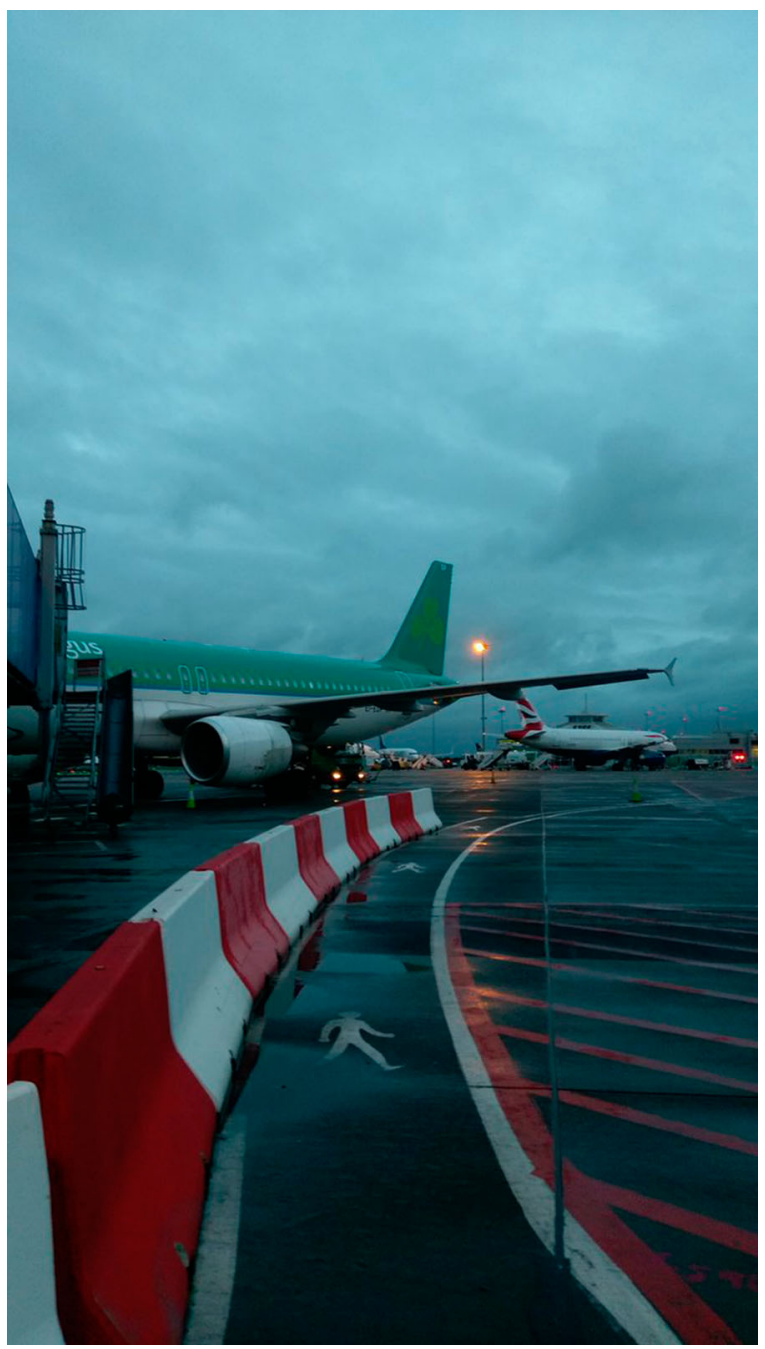

\section{FIGURE 1}

\#twowomentravel boarding, it's chilly. @EndaKennyTD

deleted, whereas mental processes, feelings and thoughts have been foregrounded. These work alongside the authenticity of images.

The language used in the posts also emphasizes others who share their experiences and viewpoint. For example:

We stand in solidarity with all women exiled by @EndaKennyTD, his predecessors, and apologists.

To all of you. We hear you and we love you. Courage and solidarity @EndaKennyTD.

Here we find extensive use of personal pronouns. In CDA it has been observed how these are very commonly used in the expression and manipulation of social relations (Van Dijk 1998, 203). On the one hand "we", "us" and "you" can be largely undefined. On the 


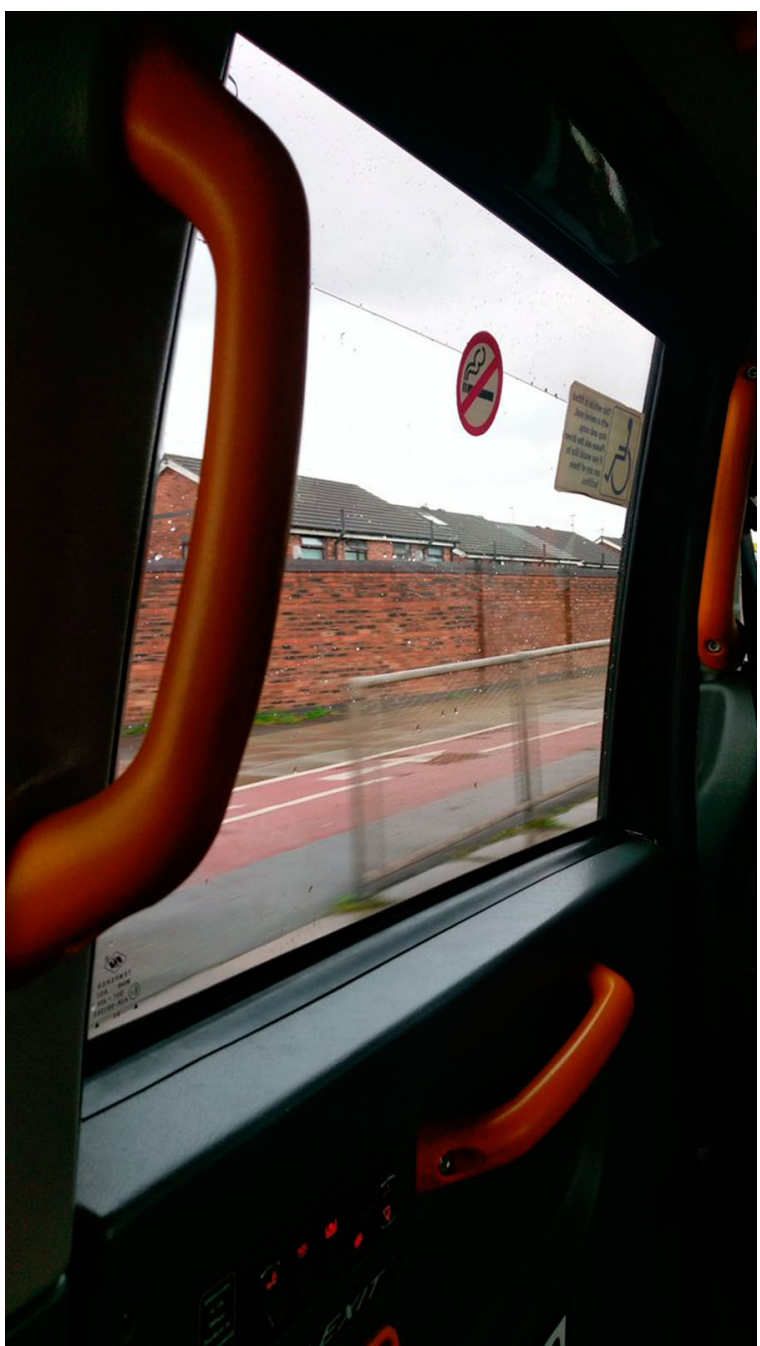

\section{FIGURE 2}

Pretty ordinary sights, in a place away from home. Can't say it's comforting, though @EndaKennyTD \#twowomentravel

other hand, it can be used to gloss over complexity, difference and conflict to create a sense of shared purpose. While the feed carries the Repeal the 8th logo, it in fact represents only one small part of the many groups who fall under its umbrella.

In this case, alongside the authenticity of the images, the mental processes, is this sense of "we" and "us". The "them" is never specifically identified apart from Enda Kenny who comes to personify the whole complex issue. Blame becomes individualized. In fact, in their final post where they make a more detailed comment on their position, @TwoWomenTravel do not present this in text form but by a photograph of a handwritten note. While it allows them to post a longer piece of text, this also provides a more personal gesture.

"Solidarity", seen in the second example above, is also often used in the posts as a word to describe the relations between those who support these actions. "Bravery" and 


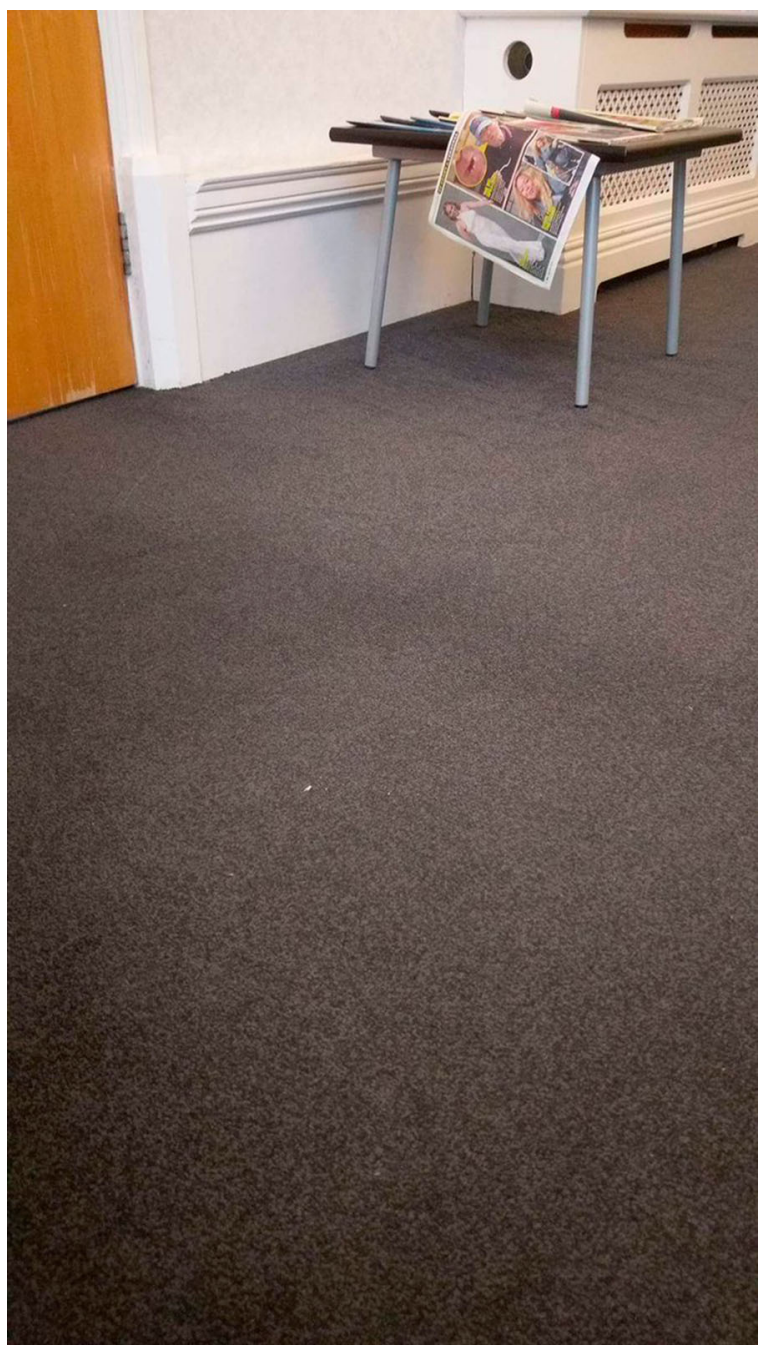

\section{FIGURE 3}

$@$ EndaKennyTD waiting room no. 2. Feel might collapse from exhaustion. No sleep. Friend calm. Brave. \#twowomentravel

"courage" are also used extensively in these posts, again detailing mental processes to evaluate the women and their actions positively. We see both of these taken up extensively by other posters in the feed, where I discuss them further.

Finally, one compelling quality of the tweets by @TwoWomenTravel is their use of simulated conversation, another important quality of successful and engaging social media language (Myers 2009). For example:

Hey @EndaKennyTD if curious RE double posting, roaming connections suck. Sure you know that anyway. \#twowomentravel

In sum, the posts use many features identified as creating compelling social media language, with a clearly identified enemy, sitting alongside a "we" based on solidarity 
and love and the intimacy created by mental processes. Alongside this, we find the "truth" and authenticity in the mundane and gritty photographs.

\section{Analysis of the Twitter Feed \#twowomentravel}

Over the two days when @TwoWomenTravel posted, there were over 40,000 tweets using the hashtag \#twowomentravel (BBC Trending 2016). Specifically, the replies to @TwoWomenTravel, as well as repostings and reactions using the hashtag \#twowomentravel tweeted on 20-21 August 2016 were included in this corpus. What I draw out here is the discourses that these carried (Van Dijk 1998). Overall, we find that while some posts were critical of the feed, most comprised highly emotional messages of support. None discussed any details about the journey, nor about the legal situation in Ireland.

\section{Bravery}

The main discourse found in the posts regarded the bravery of the women. For example:

What these women have done today is beyond important and brave @TwoWomenTravel \#repealthe8th \#twowomentravel.

@TwoWomenTravel What a brave woman u are, I am so sorry this already horrible experience has been made worse \#twowomentravel \#repealthe8th.

Throughout the feed the women and what they did are constantly evaluated as "brave". What is foregrounded therefore is not what was done, but the alleged characteristics and attitudes of the women. Such evaluations are typically ideological. For example, a news text about clashes between police and demonstrators may "overlexicalise" (Kress 1989) the bravery and courage of the police, therefore delegitimizing the actions of the demonstrators. A news report about a nation's military actions overseas may foreground the bravery of its forces over more concrete accounts of the political and economic interests in that region.

\section{Solidarity}

Alongside bravery, many posts indicated their solidarity with the women:

Today we tweeted in solidarity with \#twowomentravel while Cora shouted "Look over there!". \#repealthe8th These people need to go away.

Awed by \#twowomentravel—brave \& strong we are with you, for our sisters and our daughters and our friends. Time to \#repealthe8th.

This was done often by overtly using the term "solidarity" or by using terms like "sisters" or "women of Ireland". "Solidarity" or "sisters" signifies not simply "agreement", but a deeper moral and personal political commitment and shared alignment. It connotes things like "fights against oppression", "shared burdens". Such a position creates powerful boundaries between the kinds of perspectives that are being laid out in the tweets, between the brave ordinary women, and the view represented in individualized and personified form of Prime Minister Enda Kenny. 


\section{Expressing Love}

Many tweets expressed love. For example:

You have my support \& love, 21.6 million women experience an unsafe abortion worldwide every year \#twowomentravel.

Most of all, massive love and thanks to @TwoWomenTravel and anyone facing the same journey today, tomorrow, or the next day. \#repealthe8th.

Love was expressed both linguistically and visually through the use of hearts. Like bravery and solidarity there is an overlexicalization of "love", which in part reflects the affordances of such social media platforms that foreground communicating things such as "likes", "angry", "lol", etc. (Dean 2010). But in a different way, the "love" here works like the "ordinariness" and mental processes in the posts at the level of evaluation about the authenticity and human level of these events. In any such strategic communication, the aim is to humanize the "us" while relatively dehumanizing the enemy (Graham, Keenan, and Dowd 2004). The discursive script here becomes one of an unspecified solidarity, where actual actions are substituted and evaluated through terms such as bravery and the high positive emotions of social media.

\section{Choice}

One other important discourse in the feed was that of "choice":

Lots of people (ok men) asking why the woman at the centre of \#twowomentravel had her abortion Because she decided she needed to, that's why.

Today was a great day for Irish women and for women everywhere whose choices are denied them. \#twowomentravel

Its not that I want women to have abortions!!! I want them to have that choice if needed. \#repealthe8th \#twowomentravel

When reading Repeal the 8th material on their main website (http://www.repealeight. ie/), some of the main arguments relate to the realities of the fact that young inexperienced women do get pregnant, that a resulting child may likely live in financial hardship and also, therefore, that abortions then may be sought out in unofficial settings or require expensive travel. But in these \#twowomentravel tweets we also find abortion being aligned with a neoliberal kind of freedom of choice which scholars have related to individualism, the rise of selfgovernance and the decline of the centralized state (Jessop 2007). What is important for our understanding of the discourse or "script" here is that that this individual choice is always evaluated as good. The love, expressions of solidarity and praise of courage are infused with this sense of individualism.

\section{Context}

What we find in the original tweets by @TwoWomenTravel is that the situation and agents against which they position themselves is personified by Enda Kenny. In the rest of the feed we tend to find this expressed in more abstract terms. For example: 
Oh I know. The contrast between the bravery and the desperate situation behind \#twowomentravel and the vile abusers is scary.

Catholic Ireland? How many priests were convicted of child molestation? Catholic Ireland my vagina!!! \#twowomentravel

As we see in the first post above, the problem becomes generic as "vile abusers"; or we find that "the country" often becomes personified as the agent, through terms like "dirty old country" or here more specifically, but nevertheless generic, "Catholic Ireland". Such agents replace the complexity of voices and viewpoints on abortion.

\section{Blaming Men}

The agents of the problem, at least in a broader sense, are often identified as men. For example:

@dermotcasey @dnoting @GloriaSteinem “If men could get pregnant, abortion would be a sacrament" \#twowomentravel

@TwoWomenTravel if men got pregnant this would have been sorted years ago, safe home.

This blaming of men becomes part of the sense of "solidarity" and "sisters". The women are represented as brave yet ordinary sisters fighting for women's choice in a patriarchal and out-of-date society. In fact, however, polls show that men may more often have more liberal attitudes to abortion than women (Robbins 2014).

\section{Criticisms}

Finally, I want to look at some of the criticisms that appear in the feed. This is particularly important as regards what news reports did not take up. Some posted pictures of foetuses or newly born babies, giving information about the points at which a foetus could survive. In language, posts expressed several things:

@TwoWomenTravel @EndaKennyTD I hope the guilt of ending a life gnaws at you whilst you lie alone with your thoughts.

\#AntiLife abortion camp sinks to new low with \#twowomentravel propaganda. Even Yorkshire Ripper didn't give a blow-by-blow of his murders.

In the first place we find posts that, including pictures, point to the guilt that should be felt by the women where abortion is often referred to as murder. Of course such women may indeed feel guilt or regret, but at the same time decide that it is simply the best outcome at that time. Certainly these posts never seek to enter into dialogue with those offering solidarity. Secondly, we see posts that are more critical of the nature of the \#twowomentravel event itself:

So depressing that \#twowomentravel may move the needle on \#repealthe8th way more than the initiative of ostensibly responsible legislators.

@SourceWatchEire The crass \#twowomentravel stunt will haunt \#repealthe8th in any referendum. Public are very wary of extremism.

Possibly, @TwoWomenTravel may argue that such a strategy is simply necessary given the lack of movement in legislation over the years. Yet in this Twitter feed and 
across other social media platforms at the time, there were ongoing discussions about the nature of the \#twowomentravel event where concerns were expressed that such an uncompromising approach would simply not serve the wider aims of Repeal the 8th well, which required a much more open sense of dialogue where other powerful viewpoints would feel that they were heard.

In sum, the \#twowomentravel Twitter feed content is deeply ideological. Its discursive script recontextualizes these events where the brave fight the vile old, masculine, oppressor. It is characterized by solidarity and love and communicates its authenticity and simplicity of purpose through still and ordinary, yet striking, images. In the view of some who seek to repeal the law, \#twowomentravel may be seen as extreme and counterproductive. Yet while the images claim ordinariness, the language and design of the campaign are sophisticated and well planned. Also this appears to be a voice that fully understands journalism and the way it is now integrated into social media. I now turn to the news reports on \#twowomentravel.

\section{News Reporting on \#twowomentravel}

The analysis in this section considers how the @TwoWomenTravel events became discursively presented in news stories. I go about this analysis in three steps. These steps draw on the literature in Media and Communications studies regarding the way that (1) news is sourced; (2) events become discursively framed in ways that present them as a news story; and (3) what kind of professional work journalists carry out to provide the story. These steps allow me to draw out the way these events are discursively shaped in the news stories and reflect on the nature of the ideology that they carry.

\section{Why Did the Story Become Identified as Newsworthy and Therefore Sourced?}

Media and Communications scholars have long pointed out that what becomes news is filtered through a number of news values that tell the journalist it is newsworthy (Harcup and O'Neill 2001). These include, in later revisions of the model, things like "threshold" (in other words how gruesome something is, having large numbers of casualties, etc.); "unambiguity" (where a story must be easily understood); "meaningfulness" (where it must be culturally relevant to the audience group); and "something negative" (which allows the presentation of easily graspable "victims" and "heroes").

In the case of \#twowomentravel, the story was clearly newsworthy as regards a kind of combination of threshold and meaningfulness, since it had attracted more than 40,000 tweets. In this sense this chimes with the views of media scholars who feel that the use of social media will constitute less of a change and more likely an adaptation of former production cultures (Paulussen and Harder 2014). Here is a sense that it is treated as already meaningful to audiences since it is trending. It also fulfilled the news value of "something negative", where the tweets are seen to present a case of injustice against women.

In addition, this item was newsworthy for another reason, since it had attracted celebrity attention in the form of television personality James Corden. "Reference to elite sources", which includes politicians, officials and those known to the public, can also make an event newsworthy. In some texts this was used as a key framing device. For example, in the BBC text: 
As hundreds showed their solidarity for the woman and her companion, their actions gained attention from high-profile social media users like comedian and host of the "Late Late Show" James Corden. (BBC Trending 2016)

Also in headlines themselves, as in the Independent in Ireland:

James Corden Pledges Support to Irish Woman Live-tweeting her Abortion Journey to the UK (Murray 2016)

Finally, a highly important news value that led to the coverage of this story is that it provides the "possibility of visual material". Stories that have visuals will generally have priority over those that do not. The \#twowomentravel story comes with its own ready-made images, which is a huge advantage where resources are limited. As we discussed above, these images are particularly compelling in the way that they, through mundane and slightly dull and bleak settings, work to dramatize the journey.

Overall what we find is that, although to some extent this is an emergent way of sourcing news from trending social media feeds, its selection clearly connects to a number of traditional news values. This becomes more apparent as we further look at how the story was presented in news outlets.

\section{How Stories Become Discursively Framed}

Journalism scholars have shown that while journalists may select events according to the ways in which they fulfil certain news values, then tend to place them within well-established news frames (de Vreese 2005). These help the journalist to package the story, but it is also important as part of making stories that are easily graspable to news audiences. Media scholars have observed that as regards things like war and crime, complex conflicts become framed as good against evil (Carruthers 2000). Such frames can be usefully thought of as discourses, or the ideologically based models through which complex events become "recontextualized" (Van Leeuwen and Wodak 1999). An interesting question in this case, therefore, is how the \#twowomentravel events become discursively framed by journalists. What is the discursive "script" here?

In the news texts that carried the story, for the most part the content was comprised of the tweets by the women, including the images, interspersed with only short comments. We can look at the headlines and opening lines provided by two major news outlets.

On the BBC "trending" page of their website we find the following headline:

\#TwoWomenTravel-Live-tweeting the Journey for an Abortion (BBC Trending 2016)

Even though at the time there was speculation on other Twitter feeds as well as on \#twowomentravel that this was either a staged or "more symbolic" type of account, the BBC presents it as a factual account. The story opens with an archive photograph of women marching. A closer look at the image reveals that it is not completely clear what it shows. A woman at the front holds a "women's reproductive rights" banner'. But other protestors carry other kinds of banners, for example related to what appears to be cuts in social services.

Much has been written on this use of stock images to provide visuals for news stories (Machin 2004). Such images are cheap and quickly obtained. But they tend to lead to a culture where events become symbolized rather than documented. We see 
this kind of process here, where the image is not directly related to \#twowomentravel but symbolizes "women taking a stand". Here there is a sense that the journalists provide "context". But in this case, we can think of this on more of a ritualistic level, where the journalist does this quickly by using an image that appears to have some kind of connection.

We find the same presentation of the events in the British Guardian. Here the headline was:

Irish Woman Live-tweets Journey for Abortion in Great Britain: Woman and a Friend Thank Everyone for their Support on @TwoWomenTravel Before Beginning Trip at Dawn on Saturday (Hunt 2016)

Similarly, we also find an archive photograph here where campaigners stand outside government buildings in Dublin. Here there are more concrete and obvious links, since the women in the photograph carry Repeal the 8th banners, which the \#twowomentravel tweets also mention.

But as we saw in the analysis of the Twitter feed above, some who support Repeal the 8th are also concerned that \#twowomentravel is something extreme, that may even damage their case. What is happening in these two stories by the BBC and Guardian is that the complexity of Repeal the 8th is lost.

After such headlines, news outlets ran the @TwoWomenTravel posts, allowing the feed itself to provide the framing.

Typical of this, the following is found in the BBC story:

The description on their Twitter bio was simple: "Two Women, one procedure, 48 hours away from home". But more than 40,000 tweets about their journey revealed a conversation that was far more complex. (BBC Trending 2016)

The Irish Mirror (Brennan 2016) and the UK Daily Mirror (Evans and Brennan 2016) followed a virtually identical approach. In fact, the "complexity" mentioned here refers not to the wider social context and diversity of opinions, but the details given by the women about their struggle.

The news stories also used the discourses of bravery, courage and solidarity to frame the events. For example, the Irish Sun noted of James Corden:

And the funnyman is not the only one to pledge his support to the brave woman. The hashtag \#twowomentravel is trending on Twitter in Ireland and their page now has over 10,000 followers. (O'Rourke 2016)

The Irish Times opened their story with:

Two Irish Women Live-tweet Journey to UK for Abortion

"@TwoWomenTravel" set up "in solidarity" with those who have had to make journey. (D'Arcy and Ruxton 2016)

The pattern is that the discourses found in the news stories are the same as those found posted by @TwoWomenTravel. The headlines accept the journey on face value and the tweets that declare bravery and solidarity are allowed to speak for themselves. As in the Twitter feed, we find a discourse where heroic women battle an old patriarchal Ireland. "Context" is given in the form of the use of archive images. 


\section{Balance and Verification in Reporting}

One other strategic ritual in journalism, observed by journalism scholars, is that of "providing balance" through including different sides to a story (Bennett 2016); although journalism scholars have argued that such a process should be thought of as largely ritualistic, used to signal the neutral position of the journalist (Eriksson and Östman 2013).

What happens in the coverage of \#twowomentravel is that the framing of the events simply excludes other positions. The story is, merely, about the struggle of women against injustice. We do find some cases where journalists seek to ritually show "balance". We see this in the BBC story. Here the outlet has not actually themselves made contact with those who may have different viewpoints, but selects two tweets which offer "different perspectives". First, a tweet by the Irish Health Minister Simon Harris is given, which is described as "supporting the women":

Thanks to @TwoWomenTravel for telling story of reality which faces many. Citizens Assembly—a forum to discuss 8 th \& make recommendations.

The BBC story then tells us: "Not all were supportive", and that "Catholic blogger" Caroline Farrow criticized the women and accused them of trivializing the procedure:

This \#twowomentravel thing seems to be about using the destruction of human life for entertainment purposes. Pretty sick.

Given the nature of the actual \#twowomentravel feed and the complexity of other stances taken on the issue, this sense of presenting a balance of views, as scholars like Eriksson and Östman (2013) suggest, must be understood as little more than an enactment of a watchdog role. And given that the entire story is framed by the discourse provided by the feed, this "balance" appears as particularly tokenistic. As Lasorsa, Lewis, and Holton (2012, 23) observe, journalists use such citations, or links to other feeds, as part of creating a sense of transparency and accountability.

One other core part of the role of a journalist has been that of carrying out "verification". Verification relates to things like "facts" and "truth" (Zelizer 2004). The whole legitimacy of journalism could be thought to hang on this (Singer 2010,128). But, as Hermida (2012) points out, the increasing reliance on social media such as Twitter brings in new challenges as regards verification, which have yet to be resolved, especially given the need to provide content and updates fast and with little resources. To what extent can journalists rely on Twitter accounts of events provided by the public?

In the case of reporting \#twowomentravel, we find very little evidence of actual verification. But as with balance, we do find it at a more ritualistic level. For example, in the Guardian story we are told:

with their flight scheduled to depart at 6.30am, the pair told the Guardian they would "start moving" at 4.30am. (Hunt 2016)

Such comments appear to indicate some kind of investigation and checking by the journalist. In fact, @TwoWomenTravel remained anonymous throughout, and gave an email address where such "facts" and "background information" could be obtained. The Guardian also foreground their additional efforts by stating: 
Such a statement provides nothing to the story, but signifies "checking" and "verification". Here the word "confirmed" itself plays the important role of suggesting that additional "facts" have been dug up by the journalist. We find the same phrasing in other news outlets, such as the UK Mirror. The Irish Independent additionally stated:

Neither of the women's identities have been released thus far, but they have confirmed that they are both "well over" 18. (Murray 2016)

In sum, the role of the journalist in the reporting of \#twowomentravel certainly does not challenge the discourse found in the Twitter feed. We may even argue that the process of transporting them from social media to an official national news outlet in fact strengthens these discourses. They are no longer the voice of "likes" and expressions of excitement and emotion on a social media feed, but become the "official" situation in Ireland.

\section{Conclusion}

In CDA we have long had an interest in the role of news as regards the way it helps to disseminate, legitimize and naturalize dominant ideologies. Particularly, it has been noted how news media tend to represent the views of the powerful, of elites and official institutions. But since news sourcing has become more aligned with social media, some scholars have suggested that this may require that we rethink our model of news production and, it would seem here, that this should include the way that we attribute ideology. Given that these uses of social media are part of wide-reaching processes of cost-cutting and reorganizations in news production and delivery, we are also called to pay attention to their significance for the nature of the news that we read.

The case of \#twowomentravel shows, in particular, that specific forms of elites, or those with the professional knowhow and resources to use social media creatively, particularly here Twitter, will be in a position to have their ideologies taken up by mainstream media. This supports the findings of Papacharissi and de Fatima Oliveira (2012) and Hermida, Lewis, and Zamith (2014), which point to the way sets of influencers can come to the fore on social media, alongside traditional forms of elites. These influencers will be those who understand how social media have become very much integrated in journalism practice, who understand the processes of self-promotion and "pseudo-events" (Page 2012) that tend to lead to "trending". Becoming more often cited and gaining status as influencers may lead to them being more often used by journalists as sources.

What this analysis of the original tweets by @TwoWomenTravel also helps us to understand is how these influencers came to the fore. These women must be admired for the ways in which they understand social media communication, and for the way that they use visual communication. As we saw in our analysis above, the discourses carried by the feed included elements of feminism, but also those of brave individualism and choice, around which the affordances of social media allow "solidarity", "likes" and "love" to be loosely, yet emphatically, expressed. We might say, following Beckett and Deuze $(2016,1)$, that @TwoWomenTravel understand that media, accessed through mobile phones, are now "profoundly personalized". News and social media can be constant, and used continually as part of everyday mundane routines. In this sense, the communication that takes place through them is more personal and intimate. We engage with news events in a way that is highly emotional; and journalism here must also be able to communicate at this level. Beckett and Deuze note that it is well established that consumer attention can be prolonged through emotional 
engagement; and we know from politics that people are captured by emotion and not by logical ideas. Much news itself is now delivered through curiosity-capturing headlines. Affect is clearly as important as information. Emotional engagement is crucial for getting content shared across networks. @TwoWomenTravel in this sense was very well designed. In one sense, therefore, the use of social media here amplifies and strengthens the narrative, through emotion, and through being translated into the form of news; and in itself the feed becomes a definer of news.

This is not to say, of course, that news cannot be seen as the carrier of the ideologies passed down from traditional elites and forms of official organizations. But this small study provides one indication that, as Discourse Analysts, the way that the social goings-on behind news texts have changed through processes of integration of sourcing and delivery with social media must be something to which we must begin to pay much more attention. Also we need to be mindful of the new kinds of definers that come to the fore on social media, also with their own agenda and motivated interests.

\section{DISCLOSURE STATEMENT}

No potential conflict of interest was reported by the author.

\section{REFERENCES}

Amnesty International. 2016. "Amnesty International /Red C Poll Reveals Irish Public want Expanded Access to Abortion to be a Political Priority for Incoming Government", 4/3. https://www.amnesty.ie/amnesty-internationalred-c-poll-reveals-irish-public-want-expan ded-access-abortion-political-priority-incoming-government/.

Bacik, Ivana. 2013. "The Irish Constitution and Gender Politics: Developments in the Law on Abortion." Irish Political Studies 28 (3): 380-398.

Barthes, Roland. 1964. "Rhetoric of the Image (Rhétorique de l'image)." Communications 4: 40-51. BBC Trending. 2016. "\#TwoWomenTravel - Live-Tweeting the Journey for an Abortion." BBC 22/8. http://www.bbc.com/news/blogs-trending-37156673.

Beckett, Charlie, and Mark Deuze. 2016. "On the Role of Emotion in the Future of Journalism." Social Media+ Society 2 (3): 1-6.

Bennett, Lance. 2016. News: The Politics of Illusion. Chicago, IL: University of Chicago Press.

Brennan, Colin. 2016. "\#Twowomentravel: Irish Women Live-Tweet Journey to UK for Abortion." The Daily Mirror, 20/8. http://www.irishmirror.ie/news/irish-news/health-news/twowomen travel-irish-women-live-tweet-8669574.

Broersma, Marcel, and Todd Graham. 2012. "Social Media as Beat. Tweets as a News Source During the 2010 British and Dutch Elections." Journalism Practice 6 (3): 403-419.

Bruno, Nicola. 2011. "Tweet First, Verify Later: How Real-Time Information is Changing the Coverage of Worldwide Crisis Events." Reuters Institute for the Study of Journalism, Oxford: University of Oxford. http://reutersinstitute.politics.ox.ac.uk/publication/tweet-first-verify-later.

Caldas-Coulthard, Carmen R., and Malcolm Coulthard. 1996. "Preface." In Texts and Practices: Readings in Critical Discourse Analysis, edited by Carmen R. Caldas-Coulthard and Malcolm Coulthard, xi-xii. London: Routledge.

Carlson, Matt, and Seth C. Lewis. 2015. Boundaries of Journalism: Professionalism, Practices and Participation. London: Routledge. 
Carruthers, Susan L. 2000. The Media at War: Communication and Conflict in the Twentieth Century. Basingstoke: Palgrave/Macmillan.

Collins, Stephen. 2016. "Irish Times' Poll: Majority Want Repeal of Eighth Amendment." Irish Times 7/10. http://www.irishtimes.com/news/social-affairs/irish-times-poll-majority-want-repealof-eighth-amendment-1.2819814.

D'Arcy, Ciaran, and Dean Ruxton. 2016. "Two Irish Women Live-Tweet Journey to UK for Abortion." The Irish Times 20/8. http://www.irishtimes.com/news/ireland/irish-news/two-irishwomen-live-tweet-journey-to-uk-for-abortion-1.2763194.

de Vreese, Claes H. 2005. "News Framing: Theory and Typology." Information Design Journal + Document Design 13 (1): 51-62.

Dean, Jodi. 2010. Blog Theory. London: Polity.

Deuze, Mark. 2007. Media Work: Digital Media and Society Series. Cambridge: Polity Press.

Eriksson, Göran, and Johan Östman. 2013. “Cooperative or Adversarial? Journalists' Enactment of the Watchdog Function in Political News Production." The International Journal of Press/ Politics 18 (3): 3004-3024.

Evans, Sophie, and Colin Brennan. 2016. “\#Twowomentravel: Pregnant Irish Woman Live-Tweets her Journey to Britain with Friend for Abortion." Daily Mirror 20/8. http://www.mirror.co.uk/ news/uk-news/twowomentravel-pregnant-irish-woman-live-8671116.

Fairclough, Norman. 1992. Discourse and Social Change. Oxford: Polity Press.

Foucault, Michel. 1972. The Archaeology of Knowledge and the Discourse on Language. New York, NY: Pantheon Books.

Graham, Philip W., Thomas Keenan, and Anne-Maree Dowd. 2004. "A Call to Arms at the End of History: A Discourse-Historical Analysis of George W. Bush's Declaration of War on Terror." Discourse \& Society 15 (2-3): 199-221.

Harcup, Tony, and Deirdre O'Neill. 2001. "What is News? Galtung and Ruge Revisited." Journalism Studies 2 (2): 261-280.

Hermida, Alfred. 2012. "Tweets and Truth: Journalism as a Discipline of Collaborative Verification." Journalism Practice 6 (5-6): 659-668.

Hermida, Alfred, Seth C. Lewis, and Rodrigo Zamith. 2014. "Sourcing the Arab Spring: A Case Study of Andy Carvin's Sources on Twitter During the Tunisian and Egyptian Revolutions." Journal of Computer-Mediated Communication 19 (3): 479-499.

Hogan, Gerard. 2012. The Origins of the Irish Constitution 1928-1941. Dublin: Royal Irish Academy. Hunt, Elle. 2016. "Irish Woman Live-Tweets Journey for Abortion in Great Britain." The Guardian 20/8. https://www.theguardian.com/world/2016/aug/20/irish-woman-live-tweets-journe y-for-abortion-in-britain.

James, Frank. 2009. "Which Tweets from Iran Are True?" NPR 17/6. http://www.npr.org/blogs/ thetwo-way/2009/06/which_tweats_from_iran_are_tru.html.

Jessop, Bob. 2007. State Power. London: Wiley.

Kress, Gunther. 1989. Linguistic Processes in Sociocultural Practice. Oxford: Oxford University Press.

Lasorsa, Dominic L., Seth C. Lewis, and Avery E. Holton. 2012. “Normalizing Twitter: Journalism Practice in an Emerging Communication Space." Journalism Studies 13 (1): 19-36.

Lewis, Justin, Andrew Williams, and Bob Franklin. 2008. "A Compromised Fourth Estate?" Journalism Studies 9 (1): 1-20.

Machin, David. 2004. "Building the World's Visual Language: The Increasing Global Importance of Image Banks in Corporate Media." Visual Communication 3: 316-336. 
Machin, David, Carmen R. Caldas-Coulthard, and Tommaso M. Milani. 2016. “Doing Critical Multimodality in Research on Gender, Language and Discourse." Gender and Language 10 (3): 301-308.

Machin, David, and Andrea Mayr. 2012. How to Do Critical Discourse Analysis: A Multimodal Introduction. London: Sage.

McChesney, Robert W. 2016. "Journalism is Dead! Long Live Journalism?: Why Democratic Societies Will Need to Subsidise Future News Production." Journal of Media Business Studies 13 (3): 128-135.

McNair, Brian. 2013. "Trust, Truth and Objectivity: Sustaining Quality Journalism in the Era of the Content-Generating User." In Rethinking Journalism: Trust and Participation in a Transformed News Landscape, edited by Marcel Broersma, 76-88. London: Routledge.

Mortimer, Natalie. 2014. "Trinity Mirror Makes 'Major Investment' in Online Video as it Admits Current Offering is a "Poor Example"." The Drum 4/3. http://www.thedrum.com/news/2014/03/04/ trinity-mirror-makes-major-investment-online-video-it-admits-current-offering-poor.

Murray, Clan. 2016. "James Corden Pledges Support to Irish Woman Live-Tweeting her Abortion Journey to the UK." The Irish Independent 20/8. http://www.independent.ie/life/healthwellbeing/health-features/james-corden-pledges-support-to-irish-woman-livetweetingher-abortion-journey-to-the-uk-34980137.html.

Myers, Greg. 2009. The Discourse of Blogs and Wikis. London: Continuum.

Newman, Nic. 2009. "The Rise of Social Media and its Impact on Mainstream Journalism." Reuters Institute for the Study of Journalism. Oxford: University of Oxford. http://reutersinstitute. politics.ox.ac.uk/publication/rise-social-media-and-its-impact-mainstream-journalism.

Nichols, Bill. 1991. Representing Reality: Issues and Concepts in Documentary. Bloomington, IN: Indiana University Press.

O'Rourke, Emma. 2016. "Two women travel: James Corden shows support for Irish lady livetweeting trip to UK for abortion." The Irish Sun, accessed August 20.

Page, Ruth. 2012. "The Linguistics of Self-Branding and Micro-Celebrity in Twitter: The Role of Hashtags." Discourse and Communication 6 (2): 181-201.

Papacharissi, Zizi, and Maria de Fatima Oliveira. 2012. "Affective News and Networked Publics: The Rhythms of News Storytelling on \#Egypt." Journal of Communication 62 (2): 266-282.

Paulussen, Steve, and Raymond A. Harder. 2014. "Social Media References in Newspapers: Facebook, Twitter and YouTube as Sources in Newspaper Journalism." Journalism Practice 8 (5): 542-551.

Picard, Robert G. 2014. "Twilight or New Dawn of Journalism: Evidence From the Changing News Ecosystem." Digital Journalism 2 (3): 273-283.

Richardson, John E. 2006. Analysing Newspapers: An Approach From Critical Discourse Analysis. London: Palgrave.

Robbins, Martin. 2014. "Why are Women more Opposed to Abortion?" The Guardian 30/4. https:// www.theguardian.com/science/the-lay-scientist/2014/apr/30/why-are-women-more-opp osed-to-abortion.

Sakaki, Takeshi, Matsuo Okazaki, and Yutaka Matsuo. 2010. "Earthquake Shakes Twitter Users: Real-Time Event Detection by Social Sensors." Proceedings of the 19th international conference on world wide Web, Raleigh, NC. http://www.ymatsuo.com/papers/www2010.pdf.

Singer, Jane B. 2010. "Quality Control: Perceived Effects of User-Generated Content on Newsroom Norms, Values and Routines." Journalism Practice 4 (2): 127-142.

Van Dijk, Teun A. 1998. Ideology: A Multidisciplinary Approach. London: Sage. 
Van Leeuwen, Theo, and Ruth Wodak. 1999. "Legitimizing Immigration Control: A Discourse-Historical Analysis." Discourse Studies 1 (1): 83-118.

Winston, Brian. 2008. Claiming the Real: Documentary: Grierson and Beyond. London: BFI.

Zelizer, Barbie. 2004. "When Facts, Truth, and Reality are God-Terms: On Journalism's Uneasy Place in Cultural Studies." Communication and Critical/Cultural Studies 1 (1): 100-119.

Gwen Bouvier, Department of Media and Communication Studies, Örebro University, Sweden. E-mail: gwen.bouvier@gmail.com ORCID id http://orcid.org/0000-0003$1855-4258$ 